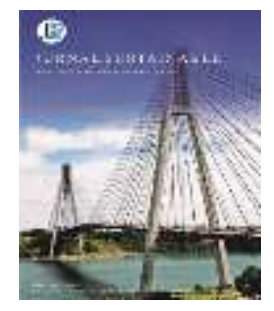

\title{
Perancangan Perangkat Penghitung Jumlah Penumpang Pada Kapal Komersial menggunakan Mikrokontroller
}

\author{
Rozeff Pramana ${ }^{1}$, Reinhard Nababan ${ }^{2}$ \\ ${ }^{1,2}$ Jurusan Teknik Elektro, Fakultas Teknik, Universitas Maritim Raja Ali Haji \\ ${ }^{1,2}$ Jl. Politeknik Senggarang, Tanjungpinang 29100 \\ Email: jeksenreinhard@yahoo.com, rozeff@umrah.ac.id
}

\begin{abstract}
One of the factors that caused the ship accident because the amount of passengers on the ship exceeded capacity. The absence of a device directly used on the ship's door to counter the amount of passengers is the cause of the excess capacity of passengers on the ship. The purpose of this study is to counter the amount of passengers on commercial vessels either entering or exiting the same door and controlling the excess amount of passengers. This passenger counter device uses two IR Obstacle sensors which function to detect and count the amount of passengers entering and exiting on the ship. The sensor reading distance is $0.1 \mathrm{~cm}$ to $56 \mathrm{~cm}$. The result of IR Obstacle sensor reading as a passenger detector will be processed using a mini computer Arduino uno displayed on the LCD as the amount of passengers. This device is equipped with LED indicators to indicate the amount of passengers on the ship. For the condition the amount of passengers exceeds the capacity then the alarm will be active and the ship starter can not be activated and for normal amount of passengers the alarm is off and the ship engine stater can be activated.
\end{abstract}

Keywords- Amount of Passengers, IR Obstacle sensor, Arduino uno, Indicator, Alarm.

Intisari- Salah satu faktor yang menjadi penyebab terjadinya kecelakaan kapal karena jumlah penumpang pada kapal melebihi kapasitas. Belum adanya perangkat yang langsung digunakan pada pintu kapal untuk menghitung jumlah penumpang menjadi penyebab terjadinya kelebihan kapasitas penumpang pada kapal. Tujuan dari penelitian ini adalah untuk menghitung jumlah penumpang pada kapal komersial baik yang masuk maupun yang keluar dari pintu yang sama dan mengkontrol jumlah penumpang yang berlebih. Perangkat penghitung jumlah penumpang ini menggunakan dua sensor IR Obstacle yang berfungsi untuk mendeteksi dan menghitung jumlah penumpang yang masuk dan keluar pada kapal. Jarak pembacaan sensor adalah $0,1 \mathrm{~cm}$ sampai 56 $\mathrm{cm}$. Hasil dari pembacaan sensor IR Obstacle sebagai pendeteksi penumpang akan diproses menggunakan mini komputer Arduino uno yang ditampilkan pada LCD berupa jumlah penumpang. Perangkat ini dilengkapi dengan indikator LED untuk mengindikasikan jumlah penumpang yang berada pada kapal. Untuk kondisi jumlah penumpang melebihi kapasitas maka alarm akan aktif dan starter kapal tidak dapat diaktifkan dan untuk jumlah penumpang normal alarm tidak aktif dan stater mesin kapal dapat diaktifkan.

Kata kunci- Jumlah Penumpang, IR Obstacle sensor, Arduino uno, Indikator, Alarm. 


\section{Pendahuluan}

Kesalahan manusia (human eror) yang sering terjadi adalah kelebihan kapasitas dari daya angkut yang telah ditetapkan, baik angkutan barang maupun angkutan orang atau penumpang. Bahkan tidak jarang pemakai jasa pelayaran memaksakan diri naik kapal meskipun kapal sudah penuh dengan tekad asal dapat tempat di atas kapal. Hal ini menjadi faktor terjadinya kecelakaan di kapal. Tercatat jumlah kecelakaan transportasi laut sendiri terus meningkat dari 18 kasus pada tahun 2016, menjadi 34 kasus kecelakaan sampai pada tahun 2017 dan 7 kasus kecelakaan transportasi laut sampai dengan 02 Februari 2018 (knkt.Dephub .go.id, 2018). Salah satu faktor yang menyebabkan kecelakaan kapal adalah terjadinya kelebihan penumpang pada kapal serta belum adanya perangkat yang diletakkan pada kapal untuk menghitung jumlah penumpang secara langsung [1].

\section{Perangkat penghitung jumlah} penumpang saat ini hanya menghitung jumlah penumpang yang akan masuk ke pelabuhan dan perhitugan penumpang untuk masuk kedalam kapal masih bersifat manual, sehingga sering kali di waktu-waktu tertentu pada saat adanya lonjakan penumpang pihak kapal dan kepelabuhan mengabaikannya dan ini akan menjadi penyebab terjadinya kecelakaan kapal karena kelebihan penumpang.

Penelitian yang berhubungan dengan perangkat penghitung jumlah penumpang pernah dilakukan [2] mengenai A Simple RealTime People Counter with Device Manageme System Using Digital Logic Design yakni sebuah alat yang menghitung jumlah orang secara real time menggunakan sistem logika. Pada penelitian ini menjelaskan sebuah alat yang dibangun menggunakan beberapa logika yang digabungkan untuk membaca atau mendeteksi jumlah orang yang akan memasuki ruangan. Sistem alat ini bekerja menggunakan sistem clck (clock) dimana diletakkan di setiap pintu masuk dan pintu keluar.
Penelitian selanjutnya yang berhubungan dengan perangkat penghitung pernah dilakukan [3] dalam jurnalnya mengenai sistem penghitung jumlah penumpang bus way berbasis mikrokontroler At89s51. Menggunakan mikrokontroler dan beberapa sensor diantaranya sensor infra merah, yang telah berkembang pesat mengikuti kemajuan ilmu pengetahuan dan teknologi. Sistem ini bekerja di sebuah bus way yaitu dengan menghitung setiap penumpang yang masuk dan mengurangi setiap penumpang yang keluar menggunakan sensor infra red sebagai pendeteksi adanya objek yang dipantulkan kemudian menampilkannya ke dalam seven segmen. Hubungannya dengan perangat ini adalah perangkat penghitung jumlah penumpang mengadopsi sistem sensor penghitung untuk diterapkan pada kapal dan mampu menghitung penumpang yang masuk dan keluar dari satu pintu yang sama.

Penelitian selanjutnya dilakukan [4] yang berjudul prototipe perangkat penghitung beban muatan pada kapal. Penelitian ini menggunakan sebuah sensor beban potensiometer yang digunakan untuk menghitung beban muatan. Hasil pembacaan sensor beban akan diproses menggunakan mini komputer Arduino uno yang ditampilkan pada LCD berupa jumlah beban muatan dan status beban muatan. Untuk kondisi beban berlebih maka alarm akan aktif dan stater mesin kapal tidak dapat diaktifkan dan untuk beban normal alarm tidak aktif dan stater mesin kapal dapat diaktifkan. Penelitian ini dinilai kurang efektif karena hanya menghitung jumlah beban muatan saja, sehingga penulis ingin melakukan pengembangan dengan menghitung jumlah penumpangnya sehingga kedepannya akan lebih efektif dalam mengurangi kecelakaan pada kapal.

Berdasarkan permasalahan ini, peneliti mengusulkan sebuah inovasi berbasis teknologi yang berfungsi untuk menghindari kelebihan penumpang di dalam kapal sehingga penumpang dapat merasakan pelayanan transportasi laut yang baik dan nyaman. Berdasarkan uraian diatas maka penulis 
R. Nababan, R. Pramana, Perancangan Perangkat Penghitung Jumlah Penumpang pada Kapal Komersial menggunakan Mikrokontroller

tertarik untuk melakukan penelitian yang berjudul "Perancangan Perangkat Penghitung Jumlah Penumpang Pada Kapal Komersial Menggunakan Mikrokontroller". Hasil dari pembacaan sensor ini akan diproses menggunakan mini komputer yang kemudian dapat ditampilkan ke dalam LCD berupa jumlah penumpang yang berada di dalam kapal tersebut dengan indikator tambahan menggunakan lampu LED dan ketika telah melebihi jumlah maksimal maka starter kapal tidak dapat diaktifkan.

\section{LANDASAN TEORI}

\section{A. Arduino Uno}

Arduino uno adalah pengendali mikro single board yang bersifat open source, diturunkan dari wiring platform, dirakit untuk memudahkan pengguna elektronika dalam berbagai bidang. Arduino uno adalah Arduino board yang menggunakan mikrokontroler ATmega328.

Arduino uno memiliki 14 pin digital (6 pin dapat digunakan sebagai output PWM), 6 input analog, sebuah $16 \mathrm{MHz}$ osilator kristal, sebuah koneksi USB, sebuah konektor sumber tegangan, sebuah header ICSP, dan sebuah tombol reset. Hanya dengan mengkoneksikannya ke sebuah komputer melalui USB atau memberikan tegangan DC dari baterai atau adaptor AC ke DC sudah dapat membuatnya bekerja. Arduino uno menggunakan ATmega16U2 yang diprogram sebagai USB-to serial converter untuk komunikasi serial ke komputer melalui port USB [5]

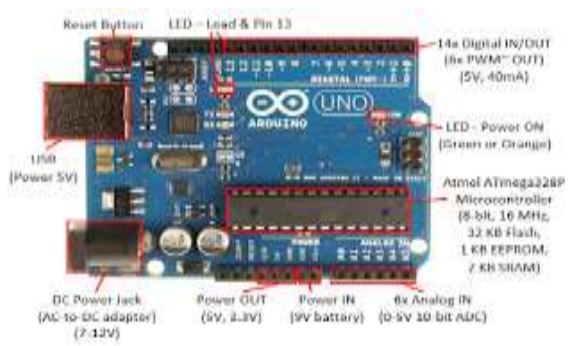

Gambar 1. Arduino uno.

\section{B. IR Obstacle Sensor}

IR Obstacle Sensor infrared merupakan sebuah modul yang berfungsi sebagai pendeteksi halangan atau object di depannya.
Contoh penggunaanya pada alarm yang berbunyi, saat sesuatu mendekat, atau mengubah arah robot ketika mendekati dinding [6].

Komponen yang terdapat di dalam sensor ini terdiri dari IR emitter dan IR receiver/ phototransistor. Cara kerjanya yaitu ketika power-up, IR emitter akan memancarkan cahaya infrared yang idak terlihat cahaya tersebut kemudian dipantulkan oleh objek yang ada di depannya. Cahaya terpantul ini kemudian diterima oleh IR receiver. Terdapat Op-Amp LM363 yang berfungsi sebagai komparator antara resistansi IR receiver dan resistansi trimpot pengatur sensitivitas. Saat terkena cahaya infrared pantulan object tadi, resistansi IR receiver akan mengecil sehingga output Op-Amp menjadi high $/ 5 \mathrm{~V}$ dan menghidupkan LED sensor. Output Op-Amp ini juga terhubung dengan pin "OUT" yang dihubungkan ke Arduino [6].

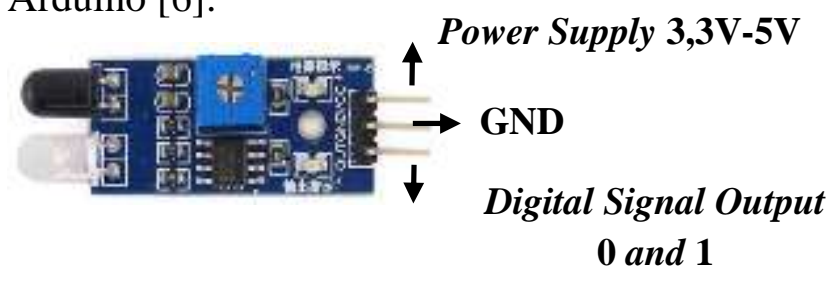

Gambar 2. IR Obstacle Sensor.

\section{LCD (Liquid Cristal Display)}

LCD merupakan suatu komponen yang berfungsi sebagai penampil (display) baik karakter maupun angka. LCD yang dipakai pada perancangan ini adalah jenis M1632 yang merupakan LCD 2x16 karakter [7].

LCD ini memerlukan tiga jalur kontrol dan delapan jalur data (untuk mode 8 bit) serta empat jalur data (untuk mode 4 bit). Ketiga jalur kontrol yang dimaksud adalah pin EN, RS dan RW [8]

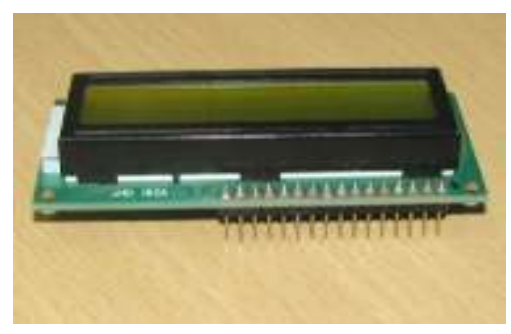

Gambar 3. LCD 16x2 


\section{Indikator LED}

Light Emitting Diode atau sering disingkat dengan LED adalah komponen elektronika yang dapat memancarkan cahaya monokromatik ketika diberikan tegangan maju. LED merupakan keluarga dioda yang terbuat dari bahan semikonduktor. Warnawarna Cahaya yang dipancarkan oleh LED tergantung pada jenis bahan semikonduktor yang dipergunakannya [9].

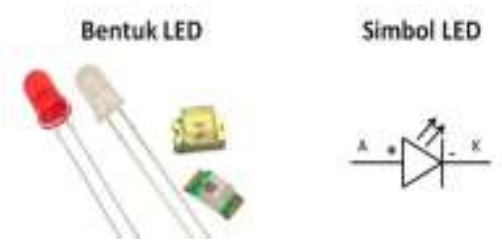

Gambar 4. Indikator LED

\section{E. Relay}

Relay adalah sebuah saklar yang dikendalikan oleh arus. Relay memiliki sebuah kumparan tegangan rendah yang dililitkan pada sebuah inti [10].

Terdapat sebuah armatur besi yang akan tertarik menuju inti apabila arus mengalir melewati kumparan. Armatur ini terpasang pada sebuah tuas berpegas. Ketika armatur tertarik, kontak jalur berubah posisinya dari kontak normal-tertutup ke kontak normalterbuka [11].

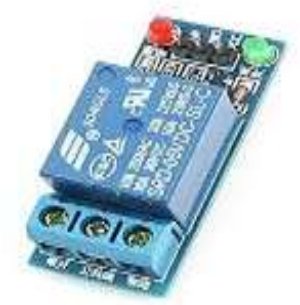

Gambar 5. Relay

\section{F. Buzzer}

Buzzer merupakan sebuah komponen elektronika yang berfungsi untuk mengkonversikan getaran listrik menjadi getaran suara [12].

Pada dasarnya prinsip kerja Buzzer hampir sama dengan loud speaker, jadi Buzzer juga terdiri dari lilitan yang terpasang pada diafragma dan kemudian lilitan tersebut dialiri arus sehingga menjadi elektromagnet, lilitan ini akan tertarik ke dalam atau keluar, tergantung dari arah arus dan polaritas magnetnya, karena kumparan dipasang pada diafragma maka setiap gerakan kumparan akan menggerakkan diafragma secara bolakbalik sehingga membuat udara bergetar yang akan menghasilkan suara [13].

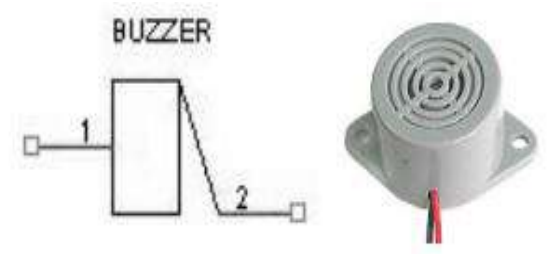

Gambar 6. Buzzer

\section{Perancangan Sistem dan CaRa KeRJa PERANGKAT}

\section{A. Perancangan Sistem}

Perancangan perangkat penghitung jumlah penumpang pada kapal komersial menggunakan mikrokontroler ini terdiri dari beberapa perangkat input yaitu sensor IR Obstacle yang berjumlah 2 buah sebagai sensor masuk dan keluar kemudian perangkat proses yang terdiri dari Arduino dan perangkat keluaran atau output yang terdiri dari LCD sebagai tampilan layar, lampu LED serta Buzzer sebagai alat indikator batasan penumpang yang digabungkan dengan sakelar otomatis untuk mematikan mesin kapal ketika kelebihan jumlah penumpang. Berikut ini blok diagram terkait dengan perancangan perangkat penghitung jumlah penumpang pada kapal komersial.

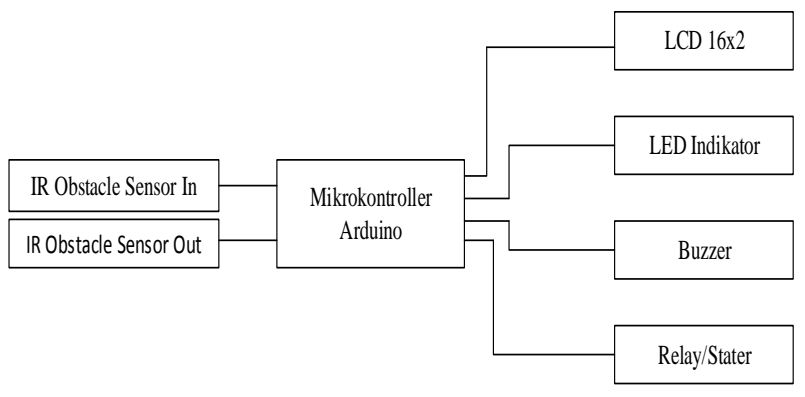

Gambar 7. Blok Diagram

Blok diagram diatas memiliki bagian input, bagian proses dan bagian output dan juga terdapat beberapa hardware penunjang yang membantu kinerja perangkat penghitung 
R. Nababan, R. Pramana, Perancangan Perangkat Penghitung Jumlah Penumpang pada Kapal Komersial menggunakan Mikrokontroller

jumlah penumpang pada kapal. Hardware tersebut seperti battery, lampu LED, Buzzer dan Relay.

Hardware penunjang ini akan membantu kinerja sistem menjadi lengkap karena hardware tersebut memiliki fungsi khusus untuk mengoptimalkan hasil kerja sistem yang dirancang. Pada gambar 8 akan dipaparkan mengenai instalasi hardware sistem.

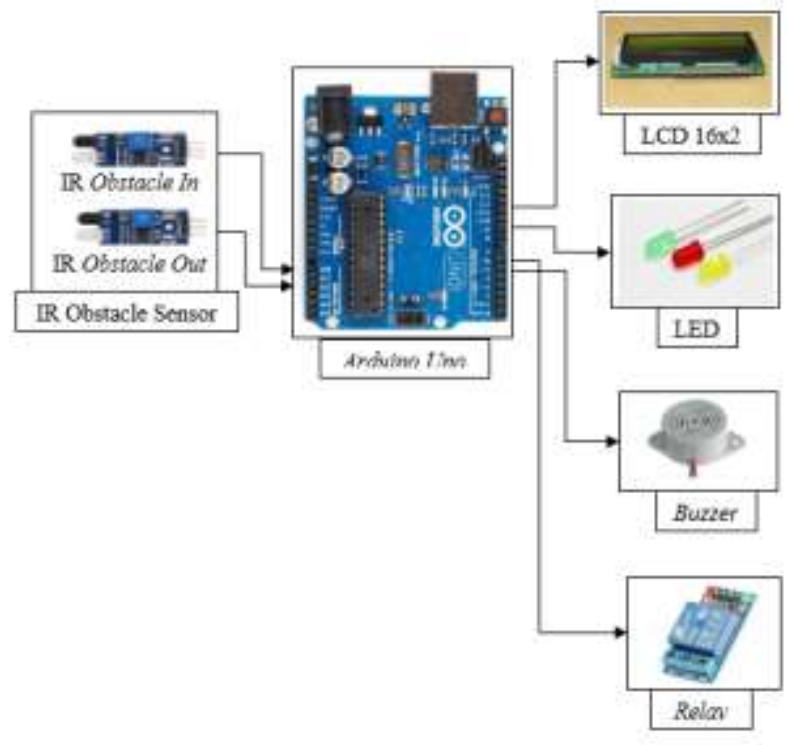

Gambar 8. Instalasi hardware sistem.

Instalasi ini akan menjadi landasan dalam pembuatan perangkat penghitung jumlah penumpang pada kapal. Instalasi ini menggunakan gambar asli dari hardware sehingga tampak seperti perangkat sebenarnya.

\section{B. Cara Kerja Perangkat}

Cara kerja perangkat ini dimulai dari sistem yang telah diaktifkan oleh catu daya, menghidupkan sensor sebagai alat input mendeteksi jumlah penumpang. IR Obstacle sensor bekerja sebagai pendeteksi keberadaan penumpang ketika memasuki kapal. Disini sensor diletakkan dua buah berguna untuk mendeteksi penumpang yang masuk dan keluar dimana mekanisme kerjanya seperti counter yaitu ketika sensor IR Obstacle In mengenai tubuh penumpang yang lewat, maka sensor ini akan mendeteksi adanya penumpang yang masuk dengan kata lain pada saat logic $H I G H$, kemudian adanya penumpang yang masuk maka logic berubah menjadi $L O W$ dan menghitung adanya penumpang yang masuk. Kemudian jika sensor IR Obstacle Out yang mengenai penumpang maka sensor ini akan bekerja menghitung adanya penumpang yang keluar dan logic HIGH pada sensor IR Obstacle Out merubah menjadi $L O W$ yang artinya menghitung jumlah keluarnya penumpang atau mengurangi jumlah penumpang yang ditampilkan di LCD 16x2. Kedua sensor ini bekerja secara bersamaan dalam penghitungannya yaitu, kedua sensor ini akan bekerja seperti counter. Jika sensor sensor IR Obstacle In bekerja maka sensor IR Obstacle Out mendapat delay dan tidak bekerja dan juga sebaliknya dilakukan untuk menghitung jumlah penumpang yang masuk maupun yang keluar dari kapal.

Buzzer dan LED berguna sebagai indikator jumlah penumpang yang telah di tentukan yaitu sebagai penanda seberapa jumlah penumpang yang telah masuk ke dalam kapal. Buzzer digunakan untuk memberi isyarat bahwa ketika jumlah penumpang melebihi batas dari jumlah yang ditentukan maka Buzzer akan berbunyi yang menandakan jumlah penumpang telah melebihi muatan. LED digunakan untuk memberi isyarat jumlah penumpang. Jika LED berwarna hijau maka kondisi jumlah penumpang masih $30 \%$, ketika LED berwarna kuning maka jumlah penumpang $70 \%$ dan jika LED berwarna merah makan jumlah penumpang $100 \%$ dan overload.

Relay digunakan untuk memberikan waktu tunda ketika penumpang telah melebihi kapasitas. Relay berfungsi seperti saklar yang dikendalikan dari fungsi logika. Relay dalam perangkat ini berfungsi sebagai tindakan selanjutnya ketika kapal kelebihan penumpang. Relay akan bekerja memutuskan saklar stater pada kapal jika penumpang pada kapal telah melebihi kapasitas. Berikut ini merupakan flowchart yang mengambarkan cara kerja perangkat dapat dilihat pada gambar 9. 


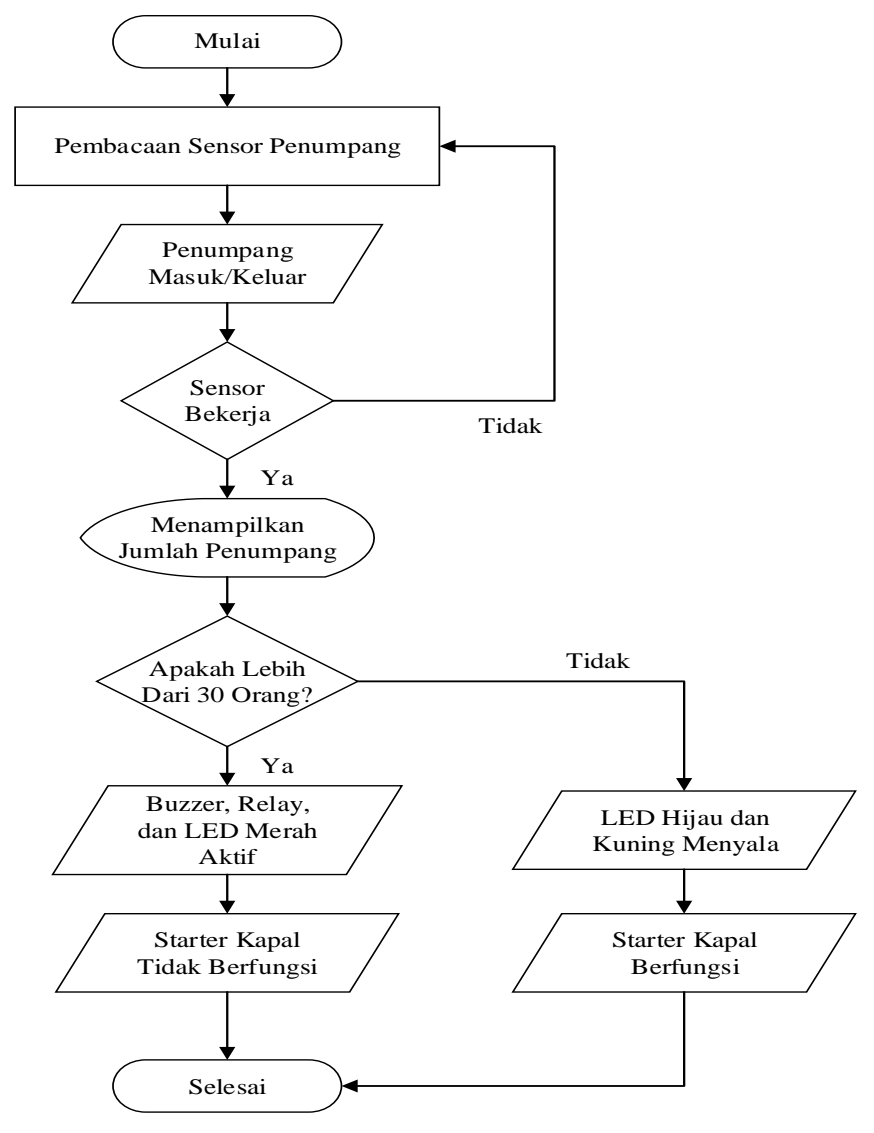

Gambar 9. Flowchart Cara Kerja Perangat

Dalam perangkat penghitung jumlah penumpang pada kapal, selain cara kerja perangkat yang telah dipaparkan perangkat ini juga menjelaskan cara kerja perangkat proses. Perangkat pemproses yang digunakan pada perancangan ini berfungi untuk memproses dan mengontrol setiap komponen yang terhubung kedalam perangkat proses. Perangkat proses yang digunakan pada perancangan ini menggunakan Arduino uno versi R3. Bebarapa pin yang terdapat pada Arduino terkoneksi dengan perangkatperangkat Input maupun Output. Power supply masuk melalui DC jack pada Arduino uno untuk memberikan sumber tegangan kepada Arduino uno. Pin A1 dan A2 digunakan sebagai sensor penghitung jumlah penumpang pada kapal, dan juga sebagai Input masukan analog ke digital kemudian diterjemahkan ke bahasa komputer melalui Arduino uno. Output yang diperoleh dari Arduino uno melalui pin A4, A5, 13, GND dihubungkan ke LCD sebagai penampilan data yang dihasilkan. Pin 9, 10, 11 sebagai output dihubungkan ke Indikator LED dan pin 5 dan pin 6 digunakan sebagai output ke Buzzer dan Relay yang digunakan untuk mengaktifkan dan menonaktifkan sakelar pada kapal. Perancangan perangkat pemproses ini dapat dilihat pada gambar 10 .

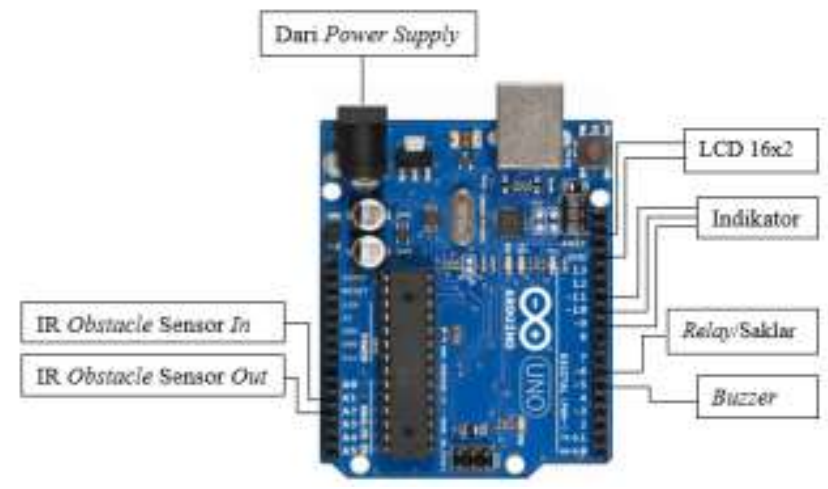

Gambar 10. Perancangan Perangkat Proses

\section{Pengujian dan ANAlisis}

\section{A. Pengujian IR Obstacle Sensor}

Pada bagian ini sensor terlebih dahulu di uji guna memastikan apakah sensor dalam keadaan baik dan dapat digunakan dengan optimal. Pada tahapan ini pengujian dilakukan dengan memberikan tegangan ke dalam sensor, kemudian tegangan diuji dengan menggunakan multimeter dan osiloskop. Berikut ini merupakan hasil pengujian sensor IR Obstacle yang akan dipaparkan pada gambar 11.

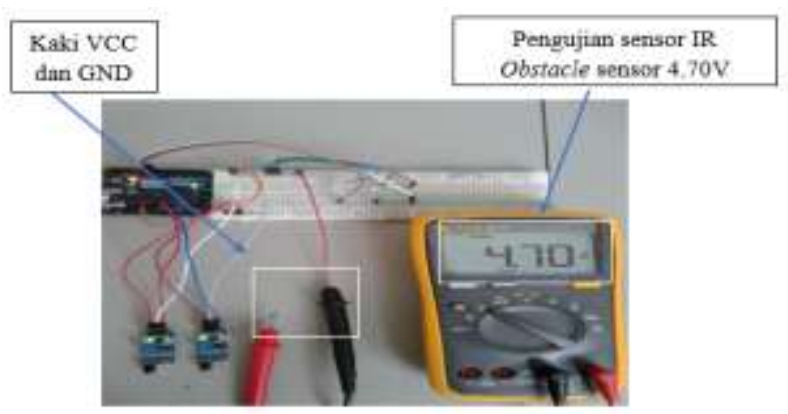

Gambar 11. Pengujian Tegangan Sensor IR Obstacle

Gambar 11 menunjukkan hasil pengukuran yang dilakukan dan diperoleh tengan pada sensor IR Obstacle sebesar 4,70 V. Untuk hasil pengujian IR Obstacle sensor secara bertahap akan dipaparkan pada tabel 1 . 
R. Nababan, R. Pramana, Perancangan Perangkat Penghitung Jumlah Penumpang pada Kapal Komersial menggunakan Mikrokontroller

Tabel 1. Pengujian IR Obstacle Sensor

\begin{tabular}{|c|c|c|c|c|c|}
\hline $\begin{array}{c}\text { Catu } \\
\text { Daya } \\
\text { (V) }\end{array}$ & Kondint & $\begin{array}{l}\text { Teganean } \\
\text { Terukur } \\
\text { (v) }\end{array}$ & $\begin{array}{c}\text { Tegangan } \\
\text { Sumber } \\
\text { (V) }\end{array}$ & $\begin{array}{c}\text { Selisih } \\
\text { (v) }\end{array}$ & Bentuk Sinyal \\
\hline & Sensior or & & & 4,97 & - \\
\hline 5 & Sensor On & 4,70 & 4,97 & $-0,27$ & \\
\hline 5 & $\begin{array}{l}\text { Tidak ada } \\
\text { Objek }\end{array}$ & 4.70 & 4,97 & $-0,27$ & \\
\hline$s$ & $\begin{array}{l}\text { Bula Ada } \\
\text { Objekc }\end{array}$ & 0,43 & 4,97 & $-4,54$ & \\
\hline 5 & $\begin{array}{c}\text { Bula } \\
\text { Berselioih }\end{array}$ & 1,74 & 4,97 & $-3,23$ & \\
\hline
\end{tabular}

Setelah melakukan pengujian tegangan pada sensor kemudian dilakukan pengujian jarak sensor. Hal ini bertujuan untuk mendapatkan hasil pembacaan sensor yang maksimal ketika menghitung jumlah penumpang yang masuk dan keluar. Hasil dari pengujian jarak menunjukkan sinyal pada osiloskop $L O W$ ketika sensor mengenai penumpang baik yang masuk maupun keluar dan $H I G H$ ketika tidak mengenai penumpang. Pengujian ini dapat kita lihat pada tabel 2.

Tabel 2. Pengujian Jarak Sensor.

\begin{tabular}{|c|c|c|c|c|}
\hline $\begin{array}{c}\text { Jarak } \\
(\mathrm{cm})\end{array}$ & $\begin{array}{c}\text { Tegangan } \\
\text { Terukur } \\
\text { (V) }\end{array}$ & $\begin{array}{l}\text { Satus } \\
\text { Sensor }\end{array}$ & Keterangan & Bentuk Sinyal \\
\hline 1 & 0,31 & Alatif & Terdeteksi & \\
\hline 20 & 0,32 & Altif & Terdeteksi & \\
\hline 40 & 0,39 & Alktif & Terdeteksi & \\
\hline 50 & 0,39 & Altif & Terdetelcsi & \\
\hline 56 & 0,41 & Altif & Terdeteksi & \\
\hline 57 & 4,70 & Altif & Tidak Terdeteksi & \\
\hline
\end{tabular}

Hasil pengujian jarak sensor menunjukkan bahwa pada jarak $56 \mathrm{~cm}$ sensor masih dapat bekerja mendeteksi media penumpang dan ketika jarak $57 \mathrm{~cm}$ sensor tidak dapat mendeteksi adanya media penumpang yang masuk maupun keluar dari kapal. Bentuk sinyal juga menunjukkan bahwa ketika adanya penumpang maka sinyal menjadi $L O W$ dan ketika tidak adanya penumpang sinyal kembali HIGH. Pengujian jarak sensor akan ditampilkan dalam bentuk grafik pada gambar 12.

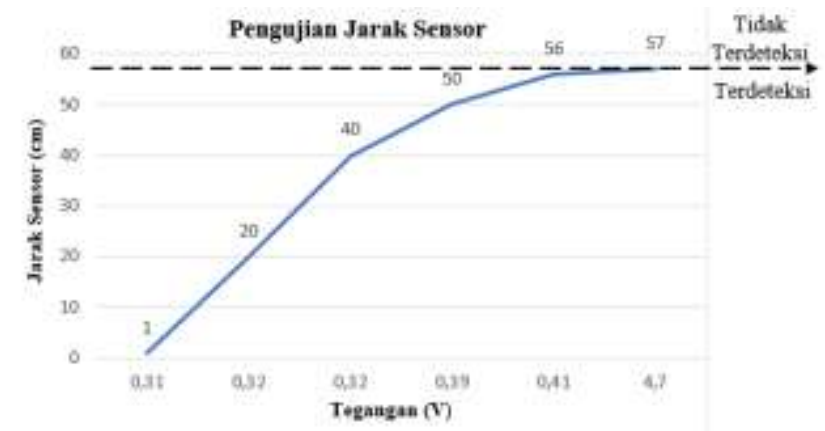

Gambar 12. Grafik Pengujian Jarak Sensor

\section{B. Pengujian Arduino Uno}

Pengujian pada Arduino Uno ini dilakukan untuk mengetahui apakah setiap port digital, analog dan pin pada Arduino uno. Sebelum melakukan pengujian di setiap pin pada Arduino uno, pengujian tegangan perlu dilakukan untuk melihat berapa tegangan yang terdapat pada Arduino uno. Berikut ini hasil pengujian tegangan pada Arduino uno menggunakan multimeter dan osiloskop pada tabel 3 .

\section{Pengujian LCD $16 \times 2$}

Pengujian LCD dilakukan untuk mengetahui pengukuran tegangan dengan baik. Pengujian LCD juga berguna untuk mengetahui dan membaca jumlah penumpang yang masuk maupun keluar dari kapal. Berdasarkan hasil pengujian yang dilakukan pada LCD menampilkan hasil pengukuran yang sesuai dengan sistem kerja sensor perhitungan penumpang. Berikut ini adalah pengujian LCD yang ditampilkan pada tabel 4 .

Dari hasil pengujian yang dilakukan pada gambar 14 menunjukkan bahwa tegangan yang diperoleh LCD sebesar $4,76 \mathrm{~V}$ pada saat LCD dalam keadaan aktif. Pengujian dilakukan dengan menghubungkan kaki VCC pada LCD ke kaki VCC pada multimeter. Kemudian kaki GND pada LCD dihubungkan 
ke kaki GND pada multimeter. Pengujian juga dilakukan di semua kaki pada LCD dan diperoleh tegangan sebesar $4,76 \mathrm{~V}$ dengan selisih tengan sumber hanya sebesar $0,21 \mathrm{~V}$. Pengujian LCD ketika tidak ada penumpang dilakukan dan hasil tegangan yang diperoleh sebesar 4,76V kemudian sinyal yang dihasilkan berupa sinyal $H I G H$ dan $L O W$. Hal ini dikarenakan pengujian dilakukan di kaki LCD yang berfungsi sebagai clock sinyal data pada LCD.

Kemudian keika penumpang masuk ataupun keluar dari kapal hasil pengujian yang diperoleh adalah tegangan sebesar $4,76 \mathrm{~V}$ dan sinyal pada osiloskop berbentuk HIGH karena adanya data yang masuk ke dalam Arduino uno yang di teruskan ke pembacaan LCD. Ketika penumpang berselisih hasil pengujian yang didapatkan adalah tegangan $4,76 \mathrm{~V}$ dan bentuk sinyal berupa $H I G H$ dan $L O W$ yang disebabkan adanya selisih penumpang yang mengakibatkan sinyal yang masuk ke LCD menjadi dua kali dan setiap masukan sinyal mempunyai delay sehingga sinyal yang dihasilkan LOW dan HIGH.

Tabel 3. Pengujian Arduino Uno

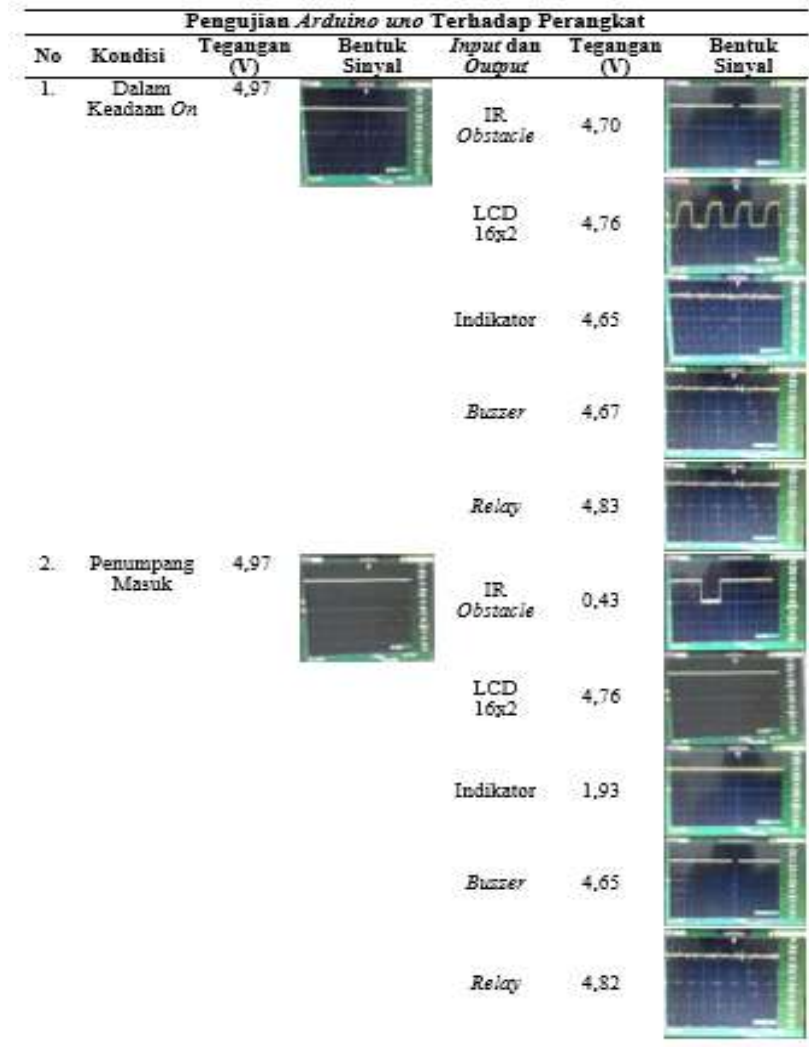

Tabel 4. Pengujian LCD

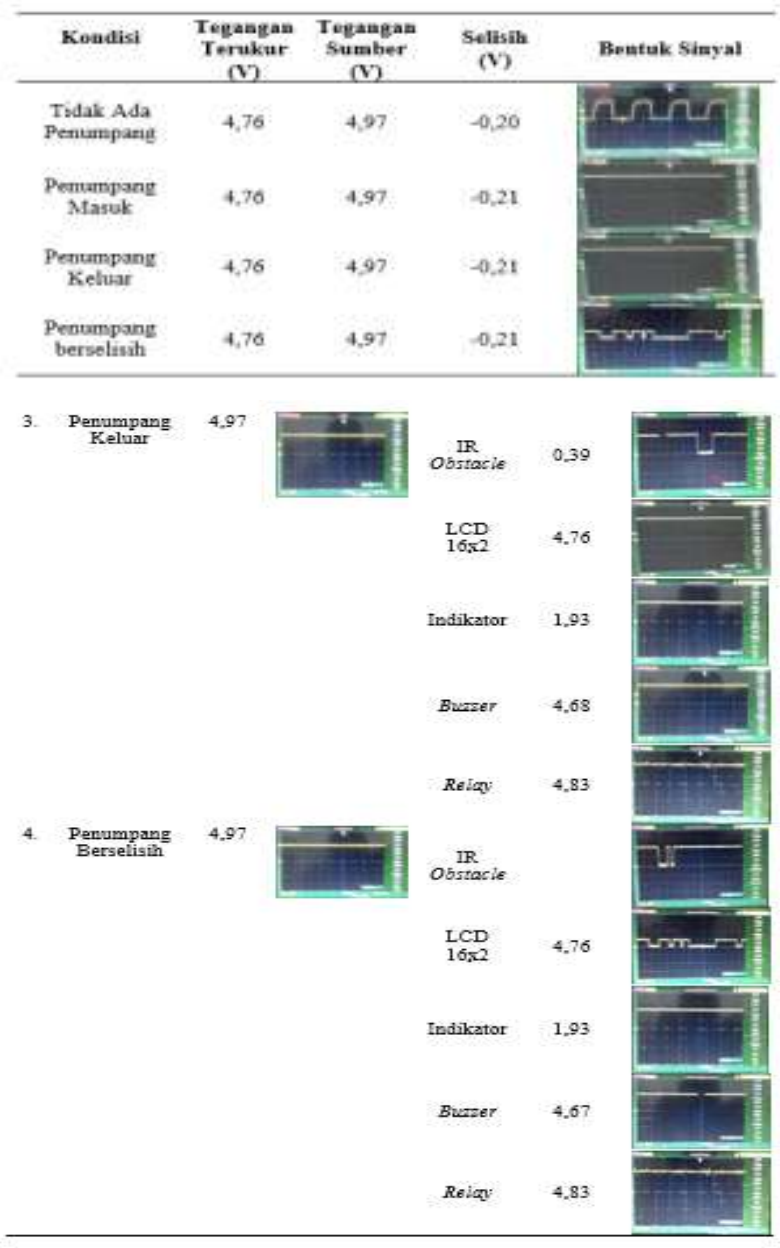

\section{Pengujian Indikator LED}

Pengujian LED bertujuan untuk mengetahui apakah LED dapat berfungsi dan bekerja dengan optimal. Parameter yang akan diuji yaitu tegangan pada LED untuk mengetahui apakah LED dapat menyala dan bekerja dengan baik. Berikut ini merupakan pengujian indikator yang dilakukan pada Tabel 5.

Hasil dari pengujian pada tabel 5 menunjukkan ketika tidak adanya penumpang tegangan yang terukur sebesar $0 \mathrm{~V}$ dan kondisi indikator LED dalam keadaan Off. Kemudian ketika penumpang masuk ataupun keluar tegangan yang diperoleh menjadi $1,93 \mathrm{~V}$ dan indikator LED hijau On yang menandakan adanya penumpang di dalam kapal dan kondisi jumlah penumpang pada kapal dalam keadaan normal. 
R. Nababan, R. Pramana, Perancangan Perangkat Penghitung Jumlah Penumpang pada Kapal Komersial menggunakan Mikrokontroller

Tabel 5. Pengujian Indikator LED

\begin{tabular}{|c|c|c|c|c|c|c|}
\hline \multirow{2}{*}{ Kondté } & \multirow{2}{*}{$\begin{array}{c}\text { Tegangan } \\
\text { Sumber } \\
\text { (v) }\end{array}$} & \multicolumn{3}{|c|}{ Koodisa Indiliator LED } & \multirow{2}{*}{$\begin{array}{c}\text { Tezangan } \\
\text { Terulaur } \\
\text { (V) }\end{array}$} & \multirow{2}{*}{ Beatak Sinyal } \\
\hline & & Merah & Kunise & Hifau & & \\
\hline $\begin{array}{l}\text { Tidalk Adi } \\
\text { Penumpang }\end{array}$ & $4.9 ?$ & $O \mathbb{2}^{\prime \prime}$ & og & off & 0,0 & \\
\hline $\begin{array}{l}\text { Penumpane } \\
\text { Manuk }\end{array}$ & 4.97 & or & at & Of & 1,03 & \\
\hline $\begin{array}{l}\text { Penumpang } \\
\text { Keluat }\end{array}$ & 4,97 & on & of & $a_{I J}$ & 1,93 & \\
\hline $\begin{array}{l}\text { Penumpang } \\
\text { Berselsih }\end{array}$ & 4,97 & on & On & OII & 1,93 & 4 \\
\hline Overioad & 4,97 & on & On & on & 1,37 & \\
\hline
\end{tabular}

Sinyal yang terbaca pada osiloskop menunjukkan ketika lampu LED menyala maka sinyal menjadi HIGH. Ketika penumpang berselisih dalam kondisi lampu LED kuning menyala yang menandakan jumlah penumpang terisi setengah, pengujian indikator dilakukan dan tegangan yang diperoleh sebesar $1,93 \mathrm{~V}$. adanya tegangan pada LED sebesar 1,93V. Pengujian kembali dilakukan saat penumpang berjumlah 31 orang atau dalam keadaan melebihi kapasitas (overload) indikator LED hijau, kuning, dan merah $O n$ atau menyala. Adanya hambatan yang dilalui tegangan sehingga tegangan yang terbaca sebesar $1,37 \mathrm{~V}$.

\section{E. Pengujian Buzzer}

Pada pengujian Buzzer ini, hal yang harus dilakukan yaitu mengaktifkan pin 5 Arduino uno untuk mengaktifkan Buzzer dengan indikator berupa lampu LED berwarna merah. Ketika jumlah penumpang telah melebihi muatan atau batas maksimal maka lampu LED dan Buzzer akan menyala. Berikut ini merupakan hasil pengujian yang dilakukan pada tabel 6 .

Tabel 6. Pengujian Buzzer

\begin{tabular}{cccc}
\hline Kondisi & $\begin{array}{c}\text { Tegangan } \\
\text { Terukur } \\
\text { (V) }\end{array}$ & $\begin{array}{c}\text { Tegangan } \\
\text { Sumber } \\
\text { (V) }\end{array}$ & $\begin{array}{c}\text { Selisih } \\
\text { (V) }\end{array}$ \\
\hline $\begin{array}{c}\text { Tidak ada } \\
\text { penumpang }\end{array}$ & 0 & 4,97 & $-4,97$ \\
$\begin{array}{c}\text { Penumpang } \\
\text { masuk }\end{array}$ & 0 & 4,97 & $-4,97$ \\
$\begin{array}{c}\text { Penumpang } \\
\text { Keluar }\end{array}$ & 0 & 4,97 & $-4,97$ \\
Overload & 4,67 & 4,97 & $-0,30$ \\
\hline
\end{tabular}

Tabel 6 menunjukkan hasil pengujian yang dilakukan pada saat tidak adanya penumpang, penumpang masuk, penumpang keluar dan ketika overload. Tegangan yang dihasilkan dari ke empat kondisi ini berbedabeda. Ketika tidak ada penumpamg tegangan yang diperoleh sebesar $0 \mathrm{~V}$ dikarenakan pada kondisi ini Buzzer dalam keadaan Off. Begitu juga dengan kondisi ketika penumpang masuk dan keluar. Selagi masih dibawah batasan jumlah penumpang maka Buzzer tetap dalam kondisi $O f f$. Ketika kondisi jumlah penumpang melebihi kapasitas atau (overload) maka tegangan dapat terbaca sebesar 4,67V. Adanya perbedaan atau selisih tegangan sebesar 0,30 terhadap Arduino uno, namun hal ini tidak berpengaruh terhadap kinerja perangkat. Tegangan tersebut mendekati tegangan sumber yang diperoleh dari sumber pin Arduino uno dan menunjukan pengujian Buzzer dapat digunakan. Pengujian Buzzer ini dilakukan dilakukan pada pin 5 Arduino uno ketika Buzzer dalam kondisi On. Kondisi On pada Buzzer terjadi ketika jumlah penumpang yang berada pada kapal telah melebihi kapasitas (overload). Suara Alaram pada Buzzer akan aktif untuk memberikan isyarat bahwa penumpang yang berada pada kapal telah melebihi kapasitas (overload).

\section{F. Pengujian Starter Kapal}

Pengujian starter kapal erat hubungannya dengan relay yang digunakan karena pada saat jumlah penumpang 31 orang, maka relay akan bekerja memberikan tegangan dan memutuskan tegangan yang semula terhubung dengan sumber tegangan eksternal. Pada pengujian ini dilakukan dengan mengaktifkan pin 11 Arduino uno sebagai output program ketika kelebihan penumpang. VCC pada relay digunakan sebagai coil untuk mengunci yang semula NO menjadi NC. Berikut ini merupakan hasil pengujian starter kapal pada Tabel 7.

Tabel 7. Pengujian Starter Kapal

\begin{tabular}{cccc}
\hline Kondisi & $\begin{array}{c}\text { Tegangan } \\
\text { Terukur } \\
(\mathbf{V})\end{array}$ & $\begin{array}{c}\text { Tegangan } \\
\text { Sumber } \\
(\mathbf{V})\end{array}$ & $\begin{array}{c}\text { Selisih } \\
\text { (V) }\end{array}$ \\
\hline $\begin{array}{c}\text { Tidak Ada } \\
\text { Penumpang }\end{array}$ & 0 & 4,97 & $-4,97$ \\
$\begin{array}{c}\text { Penumpang } \\
\text { terisi setengah } \\
\text { Overload }\end{array}$ & 0 & 4,97 & $-4,97$ \\
\hline
\end{tabular}




\section{G. Analisis}

Sensor IR Obstacle yang digunakan pada perangkat ini bekerja untuk mendeteksi adanya penumpang yang masuk ke dalam kapal maupun yang keluar dari kapal. Sensor IR Obstacle ini bekerja sepeti counter yang dapat bekerja membaca penumpang yang masuk dan keluar dari dalam kapal dalam satu pintu yang sama. IR Obstacle sensor ini mampu mendeteksi jumlah penumpang yang masuk dan keluar sampai dengan jarak $56 \mathrm{~cm}$ dan pada jarak $57 \mathrm{~cm}$ sensor ini tidak dapat mendeteksi jumlah penumpang yang masuk maupun yang keluar dari kapal. Hal ini sangat baik digunakan pada perancangan ini mengingat pintu yang digunakan pada pengujian perancangan ini memiliki lebar sebesar $61 \mathrm{~cm}$. Kemampuan pembacaan jarak sensor IR Obstacle dalam menghitung jumlah penumpang adalah $56 \mathrm{~cm}$. Terdapat dua sensor IR Obsacle In yang berfungsi mendeteksi penumpang yang masuk dan IR Obstacle Out yang berfungsi mendeteksi penumpang yang keluar. Tegangan yang dibutuhkan pada sensor ini sebesar 4,70V. Kecepatan pembacaan sensor IR Obstacle yaitu 3 detik sehingga Arduino uno dapat mengolahnya dengan baik. Sensor membaca setiap penambahan maupun pengurangan jumlah penumpang pada kapal dan diproses kedalam Arduino uno kemudian menampilkan jumlah penumpang pada perangkat LCD.

\section{Perangkat penghitung jumlah} penumpang dilengkapi dengan indikator yaitu berupa lampu LED yang berfungsi sebagai lampu yang menandakan jumlah penumpang pada kapal. Lampu LED berwarna hijau memiliki tegangan sebesar $1.93 \mathrm{~V}$ dan memiliki selisih cukup jauh dengan tegangan sumber sebesar yaitu $1,93 \mathrm{~V}-4,97 \mathrm{~V}=3,04 \mathrm{~V}$. Selisih yang terjadi dikarenakan adanya hambatan berupa resistor yang dipasang pada kaki anoda yang berfungsi untuk menurunkan tegangan sesuai dengan kebutuhan LED. Dari hasil pengujian didapatkanlah tegangan yang sesuai sehingga LED berwarna hijau dapat menyala.

Menyalanya lampu LED hijau pada perangkat ini ketika penumpang pertama masuk ke dalam kapal maka lampu LED hijau akan menyala hingga batasan jumlah penumpang yang masuk ke dalam kapal telah terisi sebagian. Perangkat ini telah dibatasi jumlah penumpang pada saat lampu LED berwarna hijau yaitu 1-15 orang penumpang. Lampu LED berwarna kuning menyala ketika penumpang telah terisi setengah hingga hampir penuh. Batasan jumlah penumpangnya adalah 16-30 orang penumpang. Tegangan yang diperoleh dari lampu LED kuning ini sama dengan lampu LED sebelumnya yaitu sebesar 1,93V. Khusus untuk lampu LED merah digunakan untuk menandakan jumlah penumpang pada kapal yang telah melebihi kapasitas (overload). Batasan ketika overload padda perangkat ini dimulai dari 31 orang penumpang. Tegangan yang diperoleh sebesar $1,37 \mathrm{~V}$ dan memiliki selisih terhadap tegangan sumber sedikit lebih banyak yaitu $4,97 \mathrm{~V}$ $1,37 \mathrm{~V}=3,6 \mathrm{~V}$ hal ini dikarenakan pada saat overload semua lampu indikator menyala sehingga tegangan pada lampu LED merah menjadi $1,37 \mathrm{~V}$. Ketika kapal telah dalam keadaan kosong, indikator LED kembali Off. Indikator LED akan kembali menyala apabila ada penumpang yang masuk ke dalam kapal. Hasil dari pengujian yang telah dilakukan pada indikator LED berjalan dengan baik dan dapat digunakan untuk menghitung jumlah penumpang pada kapal dalam bentuk indikatorLED.

Buzzer pada perangkat ini aktif ketika jumlah penumpang yang terdapat pada kapal telah melebihi kapasitas (overload). Buzzer akan aktif bersamaan dangan lampu LED merah yang menyala dan mengindikasikan bahwa penumpang yang berada pada kapal telah melebihi kapasitas (overload). Tegangan yang diperoleh ketika Buzzer aktif adalah 4,67V. Buzzer aktif ketika kaki pin 5 pada Arduino uno memberikan tegangan ke kaki positif pada Buzzer.

Sistem kerja Relay adalah memberikan tangapan atau aktif untuk menonaktifkan sistem kerja starter kapal. Tegangan yang diperoleh dari hasil pengujian adalah 4,83V . Adanya selisih yang diperoleh dari hasil pengujian yaitu $4,97 \mathrm{~V}-4,83 \mathrm{~V}=0,14 \mathrm{~V}$. 
R. Nababan, R. Pramana, Perancangan Perangkat Penghitung Jumlah Penumpang pada Kapal Komersial menggunakan Mikrokontroller

Selisih yang diperoleh masih dalam cangkupan Relay sehingga Relay dapat bekerja dengan sesuai terhadap satarter kapal. Untuk menghindari ketika terjadi (overload) dan starter dalam keadaan off atau nonaktif, maka penumpang yang berada di dalam kapal haruslah dikurangi dengan cara keluar dari pintu kapal sehinga perangkat ini dapat mengaktifkan kembali starter pada kapal. Hasil kinerja perangkat secara keseluruhan yang telah dilakukan di lapangan dimulai dari penggabungan beberapa perangkat yang terpasang dalam satu sistem berupa perangkat penghitung jumlah penumpang pada kapal komersial. Berikut ini hasil kinerja perangkat secara keseluruhan pada tabel 8 .

Taabel 8. Kinerja Perangkat Keseluruhan

Kinerja Perangkat Penghitung Jumlah Penumpang

\begin{tabular}{|c|c|c|c|c|c|c|c|}
\hline \multicolumn{2}{|c|}{$\begin{array}{c}\text { Aktivitas } \\
\text { Penumpan } \\
\text { g }\end{array}$} & \multirow{2}{*}{$\begin{array}{l}\text { Tamp } \\
\text { ilan } \\
\text { LCD }\end{array}$} & \multirow{2}{*}{$\begin{array}{c}\text { Indika } \\
\text { tor } \\
\text { Peran } \\
\text { gkat }\end{array}$} & \multirow{2}{*}{$\begin{array}{l}\text { Ala } \\
\text { rm }\end{array}$} & \multirow{2}{*}{$\begin{array}{l}\text { Kond } \\
\text { isi } \\
\text { kapal }\end{array}$} & \multirow{2}{*}{$\begin{array}{l}\text { Rel } \\
\text { ay }\end{array}$} & \multirow{2}{*}{$\begin{array}{c}\text { Starte } \\
\text { r } \\
\text { kapal }\end{array}$} \\
\hline $\begin{array}{c}\text { Mas } \\
\text { uk }\end{array}$ & $\begin{array}{l}\text { Kel } \\
\text { uar }\end{array}$ & & & & & & \\
\hline 0 & 0 & 0 & $\begin{array}{c}\text { LED } \\
\text { Off }\end{array}$ & Off & - & Off & $\begin{array}{c}\text { Berfu } \\
\text { ngsi }\end{array}$ \\
\hline 1 & 0 & 1 & $\begin{array}{c}\text { LED } \\
\text { Hijau } \\
\text { On }\end{array}$ & Off & $\begin{array}{c}\text { Norm } \\
\text { al }\end{array}$ & Off & $\begin{array}{c}\text { Berfu } \\
\text { ngsi }\end{array}$ \\
\hline 2 & 0 & 2 & $\begin{array}{c}\text { LED } \\
\text { Hijau } \\
\text { On }\end{array}$ & Off & $\begin{array}{c}\text { Norm } \\
\text { al }\end{array}$ & Off & $\begin{array}{c}\text { Berfu } \\
\text { ngsi }\end{array}$ \\
\hline 3 & 0 & 3 & $\begin{array}{c}\text { LED } \\
\text { Hijau } \\
\text { On }\end{array}$ & Off & $\begin{array}{c}\text { Norm } \\
\text { al }\end{array}$ & Off & $\begin{array}{c}\text { Berfu } \\
\text { ngsi }\end{array}$ \\
\hline 4 & 1 & 3 & $\begin{array}{c}\text { LED } \\
\text { Hijau } \\
\text { On }\end{array}$ & Off & $\begin{array}{c}\text { Norm } \\
\text { al }\end{array}$ & Off & $\begin{array}{c}\text { Berfu } \\
\text { ngsi }\end{array}$ \\
\hline 5 & 1 & 2 & $\begin{array}{c}\text { LED } \\
\text { Hijau } \\
\text { On }\end{array}$ & Off & $\begin{array}{c}\text { Norm } \\
\text { al }\end{array}$ & Off & $\begin{array}{c}\text { Berfu } \\
\text { ngsi }\end{array}$ \\
\hline 15 & 0 & 15 & $\begin{array}{c}\text { LED } \\
\text { Hijau } \\
\text { On }\end{array}$ & Off & $\begin{array}{c}\text { Norm } \\
\text { al }\end{array}$ & Off & $\begin{array}{c}\text { Berfu } \\
\text { ngsi }\end{array}$ \\
\hline 16 & 1 & 15 & $\begin{array}{l}\text { LED } \\
\text { Hijau }\end{array}$ & Off & Norm & Off & Berfu \\
\hline
\end{tabular}

\begin{tabular}{|c|c|c|c|c|c|c|c|}
\hline & & & On & & $\overline{\mathrm{al}}$ & & ngsi \\
\hline 17 & 1 & 16 & $\begin{array}{c}\text { LED } \\
\text { Kunin } \\
\text { g On }\end{array}$ & Off & $\begin{array}{c}\text { Seten } \\
\text { gah } \\
\text { Penu } \\
\text { h }\end{array}$ & Off & $\begin{array}{c}\text { Berfu } \\
\text { ngsi }\end{array}$ \\
\hline 20 & 0 & 20 & $\begin{array}{l}\text { LED } \\
\text { Kunin } \\
\text { g On }\end{array}$ & Off & $\begin{array}{c}\text { Seten } \\
\text { gah } \\
\text { Penu } \\
\text { h }\end{array}$ & Off & $\begin{array}{c}\text { Berfu } \\
\text { ngsi }\end{array}$ \\
\hline 30 & 0 & 30 & $\begin{array}{c}\text { LED } \\
\text { Kunin } \\
\text { g On }\end{array}$ & Off & $\begin{array}{c}\text { Seten } \\
\text { gah } \\
\text { Penu } \\
\text { h }\end{array}$ & Off & $\begin{array}{c}\text { Berfu } \\
\text { ngsi }\end{array}$ \\
\hline 31 & 0 & 31 & $\begin{array}{l}\text { LED } \\
\text { Mera } \\
\text { h } O n\end{array}$ & On & $\begin{array}{c}\text { Overl } \\
\text { oad }\end{array}$ & On & $\begin{array}{c}\text { Tidak } \\
\text { Berfu } \\
\text { ngsi }\end{array}$ \\
\hline
\end{tabular}

\section{KESIMPULAN}

Hasil penelitian yang telah dilakukan dapat disimpulkan sebagai berikut:

1. Perangkat penghitung jumlah penumpang pada kapal komersial dirancang dengan menggunakan Mikrokontroller Arduino uno dari sensor IR Obstacle sebagai input analog ke digital yang ditampilkan dengan menggunakan liquid crystal display.

2. Perangkat ini dapat mendeteksi penumpang yang masuk maupun keluar melalui satu pintu yang sama dari kapal dengan menggunakan sensor IR Obstacle.

3. Arduino uno adalah sebuah mikrokontroller yang dapat digunakan untuk mengontrol sensor IR Obstacle, LCD, LED, Buzzer, dan Relay sehingga sistem dapat bekerja sesuai dengan perancangan.

4. Perangkat ini dilengkapi dengan LCD sebagai tampilan jumlah penumpang dan LED yang berwarna hijau untuk kondisi jumlah penumpang yang berada di dalam kapal masih $30 \%$ atau berjumlah 15 orang, LED berwarna kuning untuk kondisi penumpang $70 \%$ atau berjumlah 30 orang dan LED berwarna merah untuk kondisi jumlah penumpang 31 orang dan tealah melebihi kapasitas (overload)

5. Melalui peringatan berupa Buzzer dan lampu LED berwarna merah yang terdapat 
pada perangkat ini, dapat digunakan untuk mengontrol jumlah penumpang yang masuk ke dalam kapal.

6. Mengaktifkan Relay sebagai tindak lanjut atau respon dari perangkat ini untuk menonaktifkan starter kapal ketika jumlah penumpang melebihi kapasitas (overload).

7. Perangkat ini dapat digunakan untuk mengurangi permasalahan dalam kepelabuhan dan pelayaran dengan mengendalikan jumlah penumpang yang masuk ke dalam kapal komersial.

8. Untuk mengaktifkan kembali starter kapal pada saat overload yaitu dengan cara mengurangi jumlah penumpang yang berada di dalam kapal sehingga dengan otomatis stater kapal dapat aktif kembali.

\section{REFERENSI}

[1] KNKT, "Data Investigasi Pelayaran Tahunan, Dinas Perhubungan Laut, Komite NasionalKeselamatan Transportasi, Jakarta.," 2016, 2016.

[2] S. M. Ismail, S. M. Fahrim, dan M. Reaz, "A Simple Real-Time People Counter With Device Management System Using Digital Logic Design," Agustus 2012, vol. 3, no. 8, Agu 2012.

[3] D. Aribowo, Desmira, dan A. Maulana, "Sistem Penghitung Jumlah Penumpang Bus Way Berbasis Mikrokontroler At89s51," Juni 2016, vol. 5, no. 1, hlm. 1, Jun 2016.

[4] M. Nopirmansyah dan R. Pramana, "Prototipe Perangkat Penghitung Beban Muatan Pada Kapal," 2017. Skripsi. Universitas Maritim Raja Ali Haji. Tanjungpinang.

[5] Arduino.cc, "Pengenalan Tenang Arduino Uno," Arduino.cc, 2018. Tersedia pada: https://www.arduino.cc. [Diakses: 22-Jan2018].

[6] Y. Ratnawati, "Tutorial Arduino IR Obstacle Sensor," Sebar Ilmu, 20-Nov2016. Tersedia pada: ebarin-ilmu. /http://tutorial-arduino-ir-obstaclesensor.html. [Diakses: 22-Jan-2018].

[7] A. Simanjuntak dan R. Pramana, "Pengontrolan Suhu Air Pada Kolam Pendederan dan Pebenihan Ikan Nila Berbasis Arduino," 2013, vol. 04, no. 01, Mei 2018.

[8] Sutono, "Sistem Monitoring Ketinggian Air," Maj. Ilm. UNIKOM, vol. 13, no. 1, hlm. 45-54, 2015.

[9] D. Kho, "Pengertian LED (Light Emitting Diode) dan Cara Kerjanya," Teknikelektronika.com, 2017. Tersedia pada:

https://teknikelektronika.com/pengertianled-light-emitting-diode-cara-kerja/. [Diakses: 28-Des-2017].

[10] Aprizal dan R. Pramana, "Rancang Bangun Sistem Monitoring Kecepatan Arus Laut Untuk Sistem Kepelabuhan. Reposiory," 2015. Universitas Maritim Raja Ali Haji.

[11] D. A. . Turang, "Pengembangan Sistem Relay Pengendalian Dan Penghematan Pemakaian Lampu Berbasis Mobile," SemnasiIF, 2015.

[12] H. Irawan dan R. Pramana, "Sistem Kamera Pengamatan Bawah Laut.," Jurnal Sustainable. Mei 2017, vol. 06, no. 01, hlm. 36-43, 19 Mei 2018.

[13] A. B. Yana, "Simbol Buzzer dan Bentuk Buzzer," Simbol Buzzer dan Bentuk Buzzer, 2010. [Diakses 09 Mei 2018]. 